\title{
Response of hemp (Cannabis sativa L.) to integrated application of chemi- cal and manure fertilizers
}

\author{
Samaneh LALEH, Majid JAMI AL-AHMADI*, Soheil PARSA
}

Received August 09, 2020; accepted April 21, 2021. Delo je prispelo 9. avgusta 2020, sprejeto 21. aprila 2021.

\begin{abstract}
Response of hemp (Cannabis sativa L.) to integrated application of chemical and manure fertilizers

Abstract: The investigation of various nutrition systems in hemp plays an influential role in improving its production. An experiment was conducted in University of Birjand, Iran, during 2013-2014, in which manure $\left(0,10,20\right.$, and 30 t.ha ${ }^{-1}$ of cow manure) was considered as the main plot and the combination of nitrogen $\left(0,50\right.$, and $100 \mathrm{~kg} \mathrm{~N} \mathrm{ha}^{-1}$ as urea) with phosphorus ( 0 and $80 \mathrm{~kg} \mathrm{P} \mathrm{ha}^{-1}$ as triple superphosphate) fertilizers was considered as factorial in subplots. The type of soil fertility management had no significant effect on the percentage of female plants. Applying 20 t.ha $^{-1}$ of manure plus $100 \mathrm{~kg} \mathrm{~N} \mathrm{ha}^{-1}$ produced the highest biological yield, seed, and leaf extract. The highest oil content was obtained by applying a maximum of 50 $\mathrm{kg} \mathrm{N} \mathrm{ha}{ }^{-1}$ without the use of phosphorus. The $30 \mathrm{tha}^{-1}$ manure plus $100 \mathrm{~kg} \mathrm{~N} \mathrm{ha}^{-1}$ increased the leaf harvest index and decreased seed harvest index. Nitrogen consumption also increased the seed oil content and yield. Phosphorus increased the biomass and extracts of seed and leaves, also biological, seeds and oil yield. It seems hemp responds well to the combined application of nitrogen fertilizer and animal manure, while its response to P fertilization was limited.
\end{abstract}

Key words: cow manure; hemp; nitrogen; oil yield; phosphorus; seed yield
Odziv konoplje (Cannabis sativa L.) na hkratno uporabo mineralnih in organskih gnojil

Izvleček: Preučevanje različnih gnojilnih režimov igra pri konoplji pomembno vlogo za izboljšanje pridelave. Na univerzi v Birjandu (University of Birjand, Iran) je bil v letih 2013-2014 izveden gnojilni poskus, $\mathrm{v}$ katerem je bilo gnojenje s kravjim gnojem glavno obravnavanje $\left(0,10,20\right.$, in $\left.30 \mathrm{t} \mathrm{ha}^{-1}\right)$ in kombinirano gnojenje $\mathrm{z}$ dušikovimi $\left(0,50\right.$, in $100 \mathrm{~kg} \mathrm{~N} \mathrm{ha}^{-1}$ kot urea) in fosforjevimi gnojili ( 0 in $80 \mathrm{~kg} \mathrm{P} \mathrm{ha}^{-1}$ kot trojni superfosfat) kot faktorski poskus na podploskvah. Način gnojenja ni imel značilnega vpliva na odstotek ženskih rastlin. Uporaba $20 \mathrm{t}$ ha $^{-1}$ kravjega gnoja $\mathrm{z}$ dodatkom $100 \mathrm{~kg} \mathrm{~N} \mathrm{ha}^{-1}$ je dala največji biološki pridelek, pridelek semena in izvlečkov listov. Največja

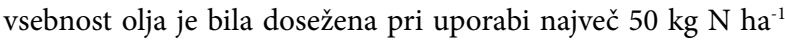
brez dodatka fosforjevega gnojila. Uporaba $30 \mathrm{t} \mathrm{ha}^{-1}$ gnoja $\mathrm{z}$ dodatkom $100 \mathrm{~kg} \mathrm{~N}^{-1}$ je povečala žetveni indeks listov in zmanjšala žetveni indeks semena. Uporaba dušikovih gnojil je tudi povečala vsebnost olja v pridelku. Dodatek fosforjevih gnojil je povečal biomaso, vsebnost snovi v izvlečkih iz listov in semen, kot tudi biološki pridelek, pridelek semena in olja. Izgleda, da se konoplja odziva dobro na kombinirano gnojenje z mineralnimi dušikovimi gnojili in živinskimi gnojili, med tem, ko je njen odziv na gnojenje s fosforjevimi mineralnimi gnojili omejen.

Ključne besede: kravji gnoj; konoplja; dušikova gnojila; pridelek olja; fosforjeva gnojila; pridelek semena

Department of Agronomy and Plant Breeding, Faculty of Agriculture, University of Birjand, Birjand, Iran mjamialahmadi@birjand.ac.ir 


\section{INTRODUCTION}

Cannabis sativa $\mathrm{L}$. is one of the oldest domesticated plants in human history and has been used since 10,000 years ago or more (Faux et al., 2013; Da Porto et al., 2014). Today, its cultivation is exposed to limitations due to the use of cannabis as a narcotic. Recently, the use of cannabis as a medicinal plant has been taken into consideration and the motive of this approach is to identify the effectiveness of whole plant cannabis in relieving some chronic diseases, although there is still debate about the medical benefits of cannabis worldwide (Madras, 2015). The seeds of this plant have a high nutritional value with a content of 22 to $35 \%$ of oil (Peiretti, 2009), and has attracted the attention of nutritionists due to its high nutritional quality (Leizer et al., 2000; García-Tejero et al., 2014). There are high concentration of bioactive components, such as cannabinoids, in Cannabis sativa L., with nutritional value associated with health benefits, which can be isolated from different parts of the plant. While large amounts of $\Delta^{9}$-THC accumulate in plant leaves, non-psychoactive cannabinoids are predominantly present in seeds (Fathordoobady et al., 2019). Meanwhile, extraction with ethanol is the preferred extraction method used for medicinal formulations (Thomas and Pollard, 2016).

The evaluation of different plant nutrition systems is one of the important needs in agronomic planning in order to achieve higher yields of plants such as hemp, as an oil or food crop. Nitrogen is one of the essential elements affecting the plants growth (Shams et al., 2013), which is required for proteins, enzymes, coenzymes, nucleic acids, cytochromes, and metabolic processes contributing to the synthesis and transfer of energy (Hoffman \& Cleemput, 2004). In hemp, the application of $240 \mathrm{~kg} \mathrm{~N} \mathrm{ha}^{-1}$ nitrogen was effective in increasing the plant biomass, stem dry mass, and inflorescence mass, compared to the control (without any fertilization) (Papastylianou et al., 2018). Poisa \& Adamovics (2010) reported an increase in the applied nitrogen fertilizer increased the yield of hemp seed, while the content of seed oil decreased in such a way that the content of hemp seed oil decreased from $42 \%$ in control plants to $40.5 \%$ in in those plants that received $100 \mathrm{~kg} \mathrm{~N} \mathrm{ha}^{-1}$.

After nitrogen, phosphorus is the second most important nutrient for plant growth, which contributes to activating coenzymes producing amino acids (Hendawy \& Khalid, 2011). Phosphorus is effective on the number of young cells in roots and stems and is highly needed in those places where cellular metabolism is greater and cells are dividing. Further, phosphorus plays a significant role in starting flowering, developing seeds and fruits, reducing diseases, increasing the quality of some crops, and root growth, especially the lateral roots, and developing fibrous root system (Hendawy et al., 2014; Kareem, 2013).

Although the use of chemical fertilizers for supplying nitrogen and phosphorus required by the plant has many benefits, there is an increasing demand for organic fertilizers, due to the soil and water pollution, and community health threats caused by synthetic chemical materials (Akande et al., 2010). The organic fertilizers (in particular, animal manures) have large amounts of organic matter, which could be used as a source of nutrients elements, especially nitrogen, phosphorus, and potassium (Cvetkov et al., 2010). Despite the benefits of using organic fertilizers, the chemical fertilizers cannot be removed from agricultural ecosystems and replaced by the organic fertilizers simultaneously, as the sustainability in agriculture is ensured by adequate income and food security. In this regard, the use of renewable and natural materials with organic sources, along with the optimal use of chemical fertilizers, can be of great importance in preserving fertility, biological building and activity, cation exchange capacity, water retention and ultimately, improving the physical and chemical structure of the soil (Ghosh et al., 2004). A large number of studies have been conducted on the integrated application of organic- with chemical fertilizers on different plants, including bean (Phaseolus vulgaris L.), soybean (Glycine max L.) (Rurangwa et al., 2018), corn (Zea mays L.) (Arif et al., 2016), sunflower (Helianthus annus L.) (Akbari et al., 2011), and coriander (Coriandrum sativum L.) (Mallanagouda et al., 1995). Generally, nutritional studies on medicinal plants indicate the positive effect of organic fertilizers on the both quantitative and qualitative yields of medicinal plants. In saffron (Crocus sativus L.), for example, the highest stigma yield was reported $0.45 \mathrm{~g} \mathrm{~m}^{-2}$ in combined treatment of manure and chemical fertilizers $\left(23 \mathrm{~kg} \mathrm{~N} \mathrm{ha}^{-1}+20 \mathrm{~kg} \mathrm{P}_{2} \mathrm{O}_{5} \mathrm{ha}^{-1}+20 \mathrm{t} \mathrm{ha}^{-1}\right.$ animal manure) (Amiri, 2009). The study of different fertilizer treatments on the German chamomile (Matricaria chamomilla L.) indicated that the combined application of manure and chemical fertilizers $\left(23 \mathrm{~kg} \mathrm{~N} \mathrm{ha}^{-1}+23 \mathrm{~kg}\right.$ $\mathrm{P}_{2} \mathrm{O}_{5} \mathrm{ha}^{-1}+7.5 \mathrm{t} \mathrm{ha}^{-1}$ cow manure) increased the biological yield (188.6\%), harvest index (18.69\%), and essential oil content ( $84.27 \%$ ), compared to the control (Shams et al., 2012).

It seems that the integrated application of appropriate amounts of organic and chemical fertilizers positively affect the oil yield of plants. For example, $50 \%$ cow manure plus $50 \%$ nitrogen in sunflower, produces the highest oil yield (1275.9 $\mathrm{kg} \mathrm{ha}^{-1}$ ), and $100 \%$ application of cow manure produces the highest oil percentage (49.4\%) (Akbari et al., 2011). In another study, the use of $50 \%$ 
cow manure plus $50 \%$ of chemical fertilizer $(\mathrm{N}, \mathrm{P}$ and $\mathrm{K}$ at 220,150 and $100 \mathrm{~kg} \mathrm{ha}^{-1}$, respectively), produces the highest yield (1482.4 $\left.\mathrm{kg} \mathrm{ha}^{-1}\right)$ and oil content $(39.7 \%)$ in sunflower (Esmaeilian et al., 2011). The combined application of organic fertilizers ( $15 \mathrm{t} \mathrm{ha}^{-1}$ vermicompost) with $100 \mathrm{~kg} \mathrm{~N} \mathrm{ha}^{-1}$ was effective in increasing the seed yield and oil content of rapeseed (Brassica napus L.) (Zahedifard et al., 2014). In a study with chemical fertilizers (nitrogen and phosphorus), and bio-fertilizer, the combination of bio-fertilizer with $50 \%$ of total nitrogen $\left(200 \mathrm{~kg} \mathrm{ha}^{-1} \mathrm{am}-\right.$ monium nitrate $33 \%$ ) and $50 \%$ of total phosphorus (100 $\mathrm{kg} \mathrm{ha}^{-1}$ of calcium superphosphate $15.5 \%$ ), produced the highest oil yield in the fennel (Foeniculum vulgare Mill.) (Dadkhah, 2012). It was reported that nitrogen fertilizer reduces the oil content of the juniper (Juniperus communis L.) (Hendawy et al., 2014), although it increases the oil yield in the thyme medicinal plant (Thymus vulgaris L.) (Baranauskienne et al., 2003).

To the best of our knowledge, the effect of the combined application of chemical and organic fertilizers on the yields of seed oil and extracts of different parts of the hemp has not yet been studied. Regarding the global trend towards the production and propagation of lowdemand crops in sustainable agricultural systems and the importance of reducing chemical inputs in agriculture on community health, more studies are necessary on the impact of chemical and organic fertilizers on neglected and new crops such as hemp, to be introduced in sustainable farming systems especially in marginal lands. This valuable plant has not yet found its true position among cash crops due to legal constraints despite the thousands of years of planting hemp (Da Porto et al., 2014). The present study aimed to investigate the effect of chemical (nitrogen and phosphorus) and organic (cow manure) fertilizers on biological, seed, leaf extract, and oil yields of hemp in two cropping years.

\section{MATERIAL AND METHODS}

The integrated application of chemical (nitrogen, phosphorus) and organic (rotted cow manure) fertilizers on hemp (Khusf landrace) was investigated during an experiment in two consecutive cropping years (2013 and 2014 ) in the Research Farm of Faculty of Agriculture $\left(32^{\circ}\right.$ $52^{\prime} \mathrm{N}, 59^{\circ} 12^{\prime} \mathrm{E}, 1491$ meters above the sea level), University of Birjand, Birjand, Iran. The seeds were obtained from smallholder farmers who grow this crop in their subsistence farming systems in the Khusf (a small town near Birjand, eastern Iran). Plant height and the length of main inflorescence of this local variety are 150 and 22 $\mathrm{cm}$, respectively, with 25-20 nodes in the main stem, on average. The stem diameter is $2-3 \mathrm{~cm}$ and the height of the first flowering node is $80 \mathrm{~cm}$. Its growth period lasts 160 to 180 days (Riahi et al., 2016)

Tables 1 and 2 represent the trends of temperature and rainfall during experiment and the characteristics of soil of experimental site and applied manure of each year, respectively. In order to determine the physical and chemical characteristics of the soil in each year, the five samples were taken prior to planting from five points through experimental site within a depth of $0-20 \mathrm{~cm}$. The samples were mixed and a sub-sample was taken. The electrical conductivity of the saturated extract and $\mathrm{pH}$ of soil and manure were measured. The nitrogen content of the soil and manure was calculated by using the Kjeldahl method (Jackson, 1958). Further, the carbon and the phosphorous of the soil and manure were measured by using Walkley-Black (Walkley and Black, 1934) and spectrophotometry (Bouyoucos, 1951), respectively. In addition, the soil texture was determined based on Bicas's hydrometer method.

The experiment was conducted in a factorial splitplot arrangement with three replications. The manure $(0$, 10,20 , and 30 tha- 1 of rotted cow manure) was considered as the main plot and the combination of nitrogen (0, 50, and $100 \mathrm{~kg} \mathrm{~N} \mathrm{ha}^{-1}$ as urea) with phosphorus (0 and $80 \mathrm{~kg} \mathrm{P}_{2} \mathrm{O}_{5} \mathrm{ha}^{-1}$ as triple superphosphate) fertilizers was considered as factorial in subplots. Generally, $100 \mathrm{~kg}$ $\mathrm{ha}^{-1}$ of potassium sulfate $\left(50 \mathrm{~kg} \mathrm{~K}_{2} \mathrm{O} \mathrm{ha}^{-1}\right.$ ) was used for all plots before sowing. All phosphorus fertilizers and half of the nitrogen fertilizers were applied before sowing below the seed planting depth. After thinning, the other half of the nitrogen fertilizer treatments (except control) were applied.

In both years, sowing was on plots that were under fallow the previous year. The manure and potassium fertilizer were spread on the soil surface and then mixed into the soil during soil preparation for sowing. The plot size consisted of 5 rows with row length of $4 \mathrm{~m}$. In each plot the hemp was sown with a density of six $\mathrm{pl} \mathrm{m}^{-2}$ (with 60 and $30 \mathrm{~cm}$ space between rows and on the rows) in five rows with a depth of $3-4 \mathrm{~cm}$. The seeds were hand sown with high density beside row bed on June 7, 2013, and May 5, 2014, and then emerged plants were thinned in two stages (when plants had 2-4 leaves and two weeks later) to achieve the final density. The irrigation interval was adjusted to 10 days. During the experiment, no herbicides, fungicides, and fertilizers (except for fertilizer treatments) were used, and all weeds were controlled by twice hand weeding early in plant growth. At final harvest, the side rows and one meter at all row ends were discarded to avoid border effects. The whole plants were harvested on November 11, 2013, and October 7, 2014, when $50 \%$ of the grains were hard. 
Table 1: Average precipitation and temperature during the growth season of hemp in 2013 and 2014

\begin{tabular}{llccccccc}
\hline & & May & June & July & August & September & October & November \\
\hline \multirow{2}{*}{2013} & Average temperature $\left({ }^{\circ} \mathrm{C}\right)$ & 21.1 & 26.7 & 27.2 & 27.2 & 23.6 & 20.9 & 10.4 \\
& Average precipitation $(\mathrm{mm})$ & 24.8 & 0.2 & 0 & 0 & 0 & 1.1 & 4.4 \\
\hline \multirow{2}{*}{2014} & Average temperature $\left({ }^{\circ} \mathrm{C}\right)$ & 22.3 & 25.7 & 28.5 & 25.3 & 22.4 & 19.6 & 13.4 \\
& Average precipitation $(\mathrm{mm})$ & 3.8 & 0.4 & 0 & 0 & 0 & 6.2 & 11.2 \\
\hline
\end{tabular}

Table 2: Physicochemical properties of the soil (0-20 cm depth) and animal manure used in 2013 and 2014

\begin{tabular}{|c|c|c|c|c|c|c|c|c|c|c|c|}
\hline \multirow[t]{2}{*}{ Year } & & $\mathrm{pH}$ & $\mathrm{EC}$ & $\begin{array}{c}\text { Organic } \\
\text { carbon }\end{array}$ & $\mathrm{N}$ & $\begin{array}{l}\mathrm{C} / \mathrm{N} \\
\text { ratio }\end{array}$ & $\mathrm{P}$ & Texture & Silt & Clay & Sand \\
\hline & & & $\left(\mathrm{dS} \mathrm{m} \mathrm{m}^{-1}\right)$ & ----- $(\%$ & ----- & & $(\mathrm{ppm})$ & & & $--(\%)$ & 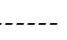 \\
\hline \multirow{3}{*}{2013} & Soil & 7.98 & 9.75 & 0.52 & 0.06 & 8.66 & 10.3 & Loamy sandy clay & 26 & 20 & 54 \\
\hline & Manure & 8.5 & 6.9 & 12.6 & 0.66 & 19.09 & 1240 & 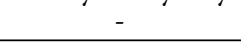 & - & - & - \\
\hline & Soil & 7.79 & 7.48 & 0.31 & 0.04 & 7.75 & 9.8 & Loamy sandy clay & 26 & 22 & 52 \\
\hline \multicolumn{12}{|l|}{2014} \\
\hline & Manure & 8.01 & 6.03 & 12.4 & 0.58 & 21.15 & 1180 & - & - & - & - \\
\hline
\end{tabular}

\subsection{MEASURED CHARACTERISTICS}

In this experiment, biological and seed yield, thousand seeds mass, leaf and seed harvest indices, the yield of leaf and seed extract, percentage and yield of seed oil, and specific leaf area (SLA) were measured. Considering the same planting density in all plots, the number of all female plants per plot was counted.

At final harvest, whole plant were harvested from three $\mathrm{m}^{2}$, and after completely drying in shading conditions and free air, were weighed on a scale $( \pm 0.01 \mathrm{~g})$ to measure biological yields of female plants. After that, seeds were separated and weighted to calculate seed yields. Five replicates of 100 seeds then were weighted with a $0.001 \mathrm{~g}$ scale to determine the mass of 1000 seeds. Also the seed and leaf harvest indices were calculated for female plants based on the leaf and seed dry yields to the biological yield ratio, respectively.

Another random sample was taken from one square meter of each plot to measure the leaf area and dry mass of female plants, and then SLA was calculated. The seed and leaves of these plants also used to measure their extracts. In this regard, we used ethanol to prepare an alcoholic extract of leaves and seeds (Khan et al., 2014). To do this, the leaves and seeds were separately grinded and $50 \mathrm{~g}$ of powdered material, after adding ethanol $70 \%$, were placed for 48 hours in a shaker incubator at $25^{\circ} \mathrm{C}$ and the speed of $100 \mathrm{rpm}$. At the end of this period, the solution was filtered by Watten's No. 1 filter paper. In order to remove the solvent from the extract, the samples were placed in a $40{ }^{\circ} \mathrm{C}$ oven for 48 hours. The obtained extract had no alcohol and contained a sticky and green substance. Then, the extracts were weighed with a 0.001 gram scale.

The extraction of seed oil was performed with the soxhlet method according to the AOAC (1990). A sample of $10 \mathrm{~g}$ of seeds flour was extracted using $100 \mathrm{ml}$ hexane as solvent, for $2 \mathrm{~h}$. The solvent was removed with a rotary evaporator and the residue was placed in oven at $100{ }^{\circ} \mathrm{C}$ for $4 \mathrm{~h}$ and then transferred to a desiccator and weighed up to constant value. The seed oil percentage was obtained by equation [1]:

Fat $(\%)=\frac{m_{3}-m_{2}}{m_{1}} \times 100$

Where $m_{1}$ represents the initial mass of the sample (g), $m_{2}$ indicates the initial mass of the container ( $\mathrm{g}$ ), and $m_{3}$ is the secondary mass of the container (container + oil). The oil yield was simply obtained by multiplying seed yield in the oil percentage.

The specific leaf area $\left(\mathrm{cm}^{2} \mathrm{~g}^{-1}\right)$ was calculated from the equation [2] (Amanullah et al., 2007):

$S L A=\frac{L A}{L W}$

Where LA represents the leaf area $\left(\mathrm{cm}^{2} \mathrm{pl}^{-1}\right)$ and LM indicates the leaf mass per plant $\left(\mathrm{g} \mathrm{pl}^{-1}\right)$. For this purpose, 
in the seed filling stage, female plants were harvested from one $\mathrm{m}^{2}$ of each plot, and their leaves were separated. Leaf area was determined using a leaf area meter (DeltaT Devices, UK).

\subsection{STATISTICAL ANALYSIS}

In the present study, check the normality of data, plotting, and analysis of regressions, as well as the correlations of traits were done by IBM SPSS Statistics 22 software. Before the combined analysis of the data, Bartlett's test was used to ensure the uniformity of the test error variance. Data analysis was performed using SAS 9.2 software considering the effect of year as random and the effect of experimental treatments for desired traits as constant. Comparison of meanings was done by FLSD test at 5\% probability level.

\section{RESULTS AND DISCUSSION}

\subsection{RESULTS}

Table 3 shows the results of analysis of variance of traits. As shown in Table 4, the studied traits were not significantly different between two years. The fertilizer treatments had no significant effect on the percentage of female plants in the hemp. However, an increase in the manure level and also applying $50 \mathrm{~kg} \mathrm{~N}^{-1}$ increased the percentage of female plants. Bigger increase in the nitrogen fertilizer level reduced the percentage of female plants, which was not significant (Table 4).

By comparing biological yield among different manure levels, the most beneficial effect of manure on increasing biological yield was achieved from 10 to $20 \mathrm{t} \mathrm{ha}^{-1}$ applied manure, that was on average $148.94 \mathrm{~kg} \mathrm{ha}^{-1}$ biological yield per each one $\mathrm{tha}^{-1}$ of more manure; although a further increase in the manure amount reduced its effectiveness in increasing the biological yield (Table 4). An increase in the nitrogen amounts also reduced its effect on enhancing biological yield, such that the increase in biological yield per each kg more nitrogen between 0-50 $\mathrm{kg} \mathrm{N} \mathrm{ha}^{-1}$ (44.4 $\mathrm{kg} \mathrm{ha}^{-1}$ ) was more than 50-100 kg N ha-1 (13.61 kg N ha-1) (Table 4).

The highest biological yield was obtained in the combined treatment of $20 \mathrm{t} \mathrm{ha}^{-1}$ manure plus $100 \mathrm{~kg} \mathrm{~N}$ $\mathrm{ha}^{-1}$, which did not show any significant difference with the combined treatment of $30 \mathrm{tha}^{-1}$ manure plus $50 \mathrm{~kg} \mathrm{~N}$ $\mathrm{ha}^{-1}$ (Table 5). Without the applying manure, for increasing each $\mathrm{kg} \mathrm{N} \mathrm{ha}^{-1}$ from the 0 to 50 and 50 to $100 \mathrm{~kg} \mathrm{~N}$ ha 1 , the biological yield increased, on average by 29.4 and $21.4 \mathrm{~kg} \mathrm{ha}^{-1}$, respectively. When $10 \mathrm{t} \mathrm{ha}^{-1}$ cow manure was used, the increase in the biological yield was 35.22 and $17.9 \mathrm{~kg} \mathrm{ha}^{-1}$ per each $\mathrm{kg} \mathrm{N}$ in $0-50$ and $50-100 \mathrm{~kg} \mathrm{ha}^{-1}$ applied $\mathrm{N}$, respectively. These increases in biological yield for $20 \mathrm{t} \mathrm{ha}^{-1}$ of manure were 54.28 and $20 \mathrm{~kg} \mathrm{ha}^{-1}$, respectively. At the level of $30 \mathrm{t} \mathrm{ha}^{-1}$ manure, the biological yield increased by an average of $57.25 \mathrm{~kg} \mathrm{ha}^{-1}$ per each $\mathrm{kg} \mathrm{N}$ $\mathrm{ha}^{-1}$ in the range from 0 to $50 \mathrm{~kg} \mathrm{~N} \mathrm{ha}^{-1}$ while it decreased by $18.38 \%$ per each $\mathrm{kg}$ of nitrogen in the range $50-100 \mathrm{~kg}$ $\mathrm{N} \mathrm{ha}^{-1}$. This indicates the use of manure has been effective in increasing the effectiveness of nitrogen fertilizer. In each level of manure, the efficiency of adding first 50 $\mathrm{kg} \mathrm{N} \mathrm{ha}^{-1}$ (0-50 $\left.\mathrm{kg} \mathrm{N} \mathrm{ha}^{-1}\right)$ to improve biological yield was more than that of the second $50 \mathrm{~kg}\left(50-100 \mathrm{~kg} \mathrm{~N} \mathrm{ha}^{-1}\right)$, confirming that the response of biological yield to the amount of consumed nitrogen follows law of diminishing returns. The results also indicated that an increase in the nitrogen levels to $100 \mathrm{~kg} \mathrm{ha}^{-1}$ could have a negative effect on the biological yield of hemp for levels of more than $20 \mathrm{t} \mathrm{ha}^{-1}$ of manure (Table 5).

Based on the results, the beneficial effect of nitrogen on the seed yield increased under the influence of manure, and accordingly, no significant difference was observed between 0 and $50 \mathrm{~kg} \mathrm{~N}$ ha $^{-1}$ when manure was not used. However, manure was applied at rates of 10, 20, and $30 \mathrm{t} \mathrm{ha}^{-1}$, the use of $50 \mathrm{~kg} \mathrm{~N} \mathrm{ha}^{-1}$ could significantly increase the seed yield by $29.33 \%, 33.9 \%$, and $33.75 \%$, respectively, compared to non-application of nitrogen (Table 5). The highest seed yield was achieved when 20 t ha-1 manure was used along with $100 \mathrm{~kg} \mathrm{~N} \mathrm{ha}^{-1}$, which increased by $40.95 \%$ compared to when the manure was not used. Further, there was no significant difference between the combined applications of $20 \mathrm{t} \mathrm{ha}^{-1}$ of manure plus $100 \mathrm{~kg} \mathrm{~N} \mathrm{ha}^{-1}$ with $20 \mathrm{t} \mathrm{ha}^{-1}$ manure with $50 \mathrm{~kg} \mathrm{~N}$ $\mathrm{ha}^{-1}$, and $30 \mathrm{t} \mathrm{ha}^{-1}$ manure plus $50 \mathrm{~kg} \mathrm{~N} \mathrm{ha}^{-1}$ (Table 5). It is worth noting that an increase in the nitrogen fertilizer level increased the seed yield at 0,10 , and $20 \mathrm{tha}^{-1}$ of manure, while the use of $100 \mathrm{~kg} \mathrm{~N} \mathrm{ha}^{-1}$ could not positively affect the seed yield when combined with $30 \mathrm{t}$ ha- 1 of manure. This combined treatment reduced the seed yield by $17.11 \%$, compared to a combined use of $30 \mathrm{t} \mathrm{ha}^{-1} \mathrm{ma}$ nure plus $50 \mathrm{~kg} \mathrm{~N} \mathrm{ha}^{-1}$ (Table 5).

The response of seed yield to manure was followed a second-order function under the influence of phosphorus consumption, upon which, when phosphorus was applied, the highest seed yield was obtained with the application of $20 \mathrm{t} \mathrm{ha}^{-1}$ manure; however when phosphorus was not consumed, the response of the seed yield to manure was linear (Figure 1). Therefore, in the case of phosphorus application, the use of more than $20 \mathrm{t} \mathrm{ha}^{-1}$ manure reduced the effectiveness of manure to increase the seed yield, while, in the case of non-application of phosphorus, as the amount of manure increased, seed yield also 


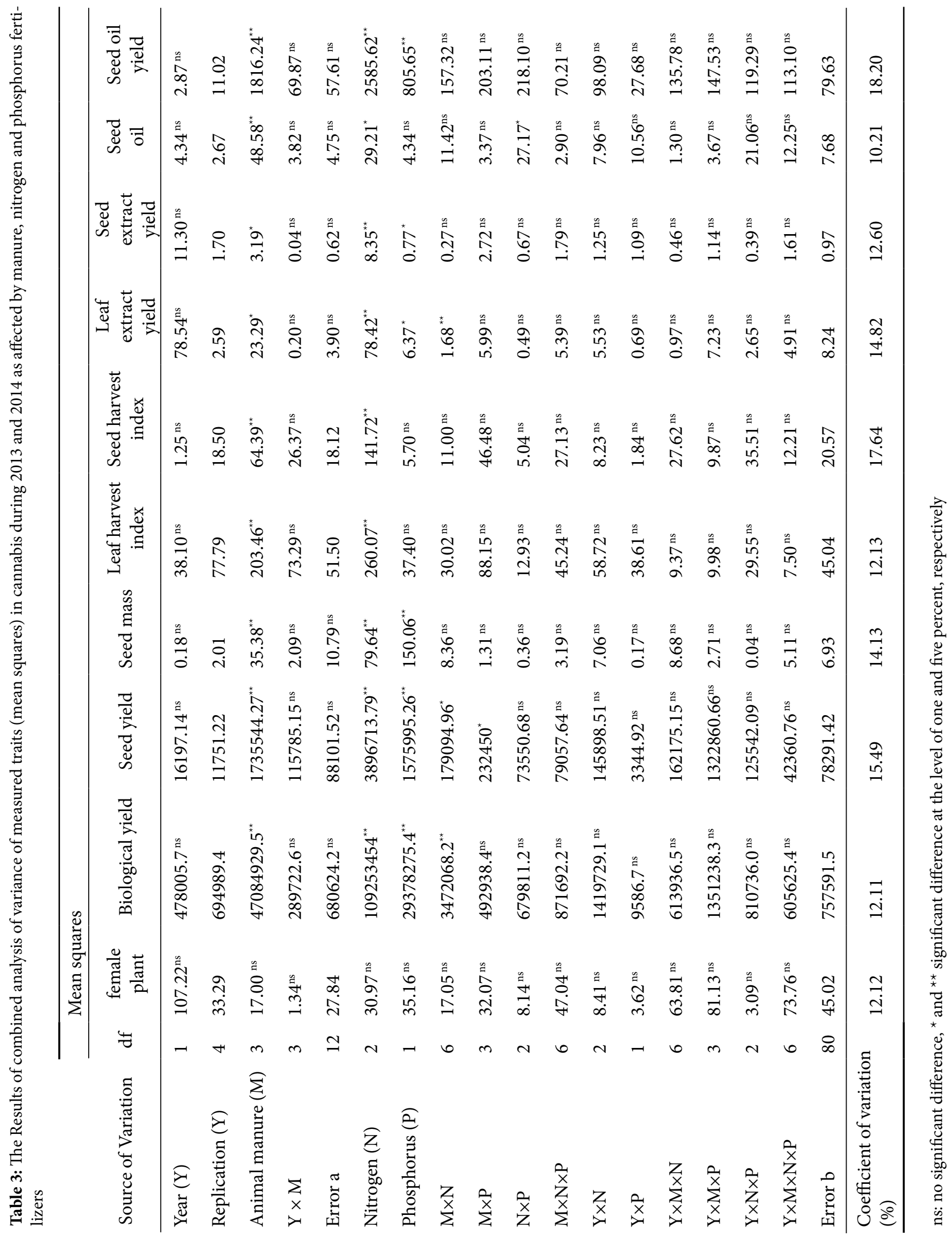


Table 4: Simple effects of animal manure, nitrogen and phosphorus on measured traits in hemp. For fertilization treatments, numbers are means of three replication \pm SEM

\begin{tabular}{|c|c|c|c|c|c|c|c|c|c|c|c|}
\hline Trea & Level & $\begin{array}{c}\text { female } \\
\text { plant } \\
(\%) \\
\end{array}$ & $\begin{array}{l}\text { Biological } \\
\text { yield (kg } \\
\left.\text { ha }^{-1}\right)\end{array}$ & $\begin{array}{c}\text { Seed } \\
\text { yield (kg } \\
\left.\text { ha }^{-1}\right)\end{array}$ & $\begin{array}{c}\text { Seed } \\
\text { mass } \\
\text { (g } 1000 \\
\text { seed) }\end{array}$ & $\begin{array}{c}\text { Leaf } \\
\text { harvest } \\
\text { index } \\
(\%)\end{array}$ & $\begin{array}{c}\text { Seed } \\
\text { harvest } \\
\text { index } \\
(\%)\end{array}$ & $\begin{array}{c}\text { Leaf } \\
\text { extract } \\
\text { yield }(\mathrm{kg} \\
\left.\mathrm{ha}^{-1}\right) \\
\end{array}$ & $\begin{array}{c}\text { Seed } \\
\text { extract } \\
\text { yield }(\mathrm{kg} \\
\left.\mathrm{ha}^{-1}\right) \\
\end{array}$ & $\begin{array}{c}\text { Seed oil } \\
(\%)\end{array}$ & $\begin{array}{c}\text { Seed oil } \\
\text { yield (kg } \\
\left.\text { ha-1 }^{-1}\right)\end{array}$ \\
\hline \multirow{2}{*}{ Yea } & 2013 & $54.48^{\mathrm{a}}$ & $7242.34^{\mathrm{a}}$ & $1795.29^{\mathrm{a}}$ & $18.58^{\mathrm{a}}$ & $54.79^{\mathrm{a}}$ & $25.61^{\mathrm{a}}$ & $787.40^{\mathrm{a}}$ & $88.83^{\mathrm{a}}$ & $27.30^{\mathrm{a}}$ & $488.77^{\mathrm{a}}$ \\
\hline & 2014 & $56.20^{\mathrm{a}}$ & $7127.11^{a}$ & $1816.50^{\mathrm{a}}$ & $18.66^{\mathrm{a}}$ & $55.82^{\mathrm{a}}$ & $25.74^{\mathrm{a}}$ & $807.32^{\mathrm{a}}$ & $78.14^{a}$ & $26.95^{\mathrm{a}}$ & $491.59^{\mathrm{a}}$ \\
\hline \multirow{4}{*}{$\begin{array}{c}\text { Animal } \\
\text { manure } \\
\left.\text { ha }^{-1}\right)\end{array}$} & 0 & $5462^{2}$ & $5858.80^{c}$ & 1074 & $17.47^{\mathrm{b}}$ & $52.76^{c}$ & $27.03^{\mathrm{a}}$ & $599.50^{\mathrm{b}}$ & $66.52^{\mathrm{b}}$ & $25.52^{\mathrm{b}}$ & $394.02^{c}$ \\
\hline & 10 & $55.00^{\mathrm{a}}$ & $6602.00^{\mathrm{b}}$ & $1710.41^{\mathrm{c}}$ & $18.13^{\mathrm{ab}}$ & $53.88^{\mathrm{bc}}$ & $26.31^{\mathrm{a}}$ & $685.19^{\mathrm{b}}$ & $74.95^{\mathrm{b}}$ & $28.22^{\mathrm{a}}$ & $483.94^{\mathrm{b}}$ \\
\hline & 20 & $55.54^{\mathrm{a}}$ & $8091.40^{\mathrm{a}}$ & $2027.85^{a}$ & $19.47^{\mathrm{a}}$ & $56.72^{\mathrm{ab}}$ & $25.56^{\mathrm{ab}}$ & $939.89^{\mathrm{a}}$ & $98.67^{a}$ & $27.66^{\mathrm{a}}$ & $558.77^{\mathrm{a}}$ \\
\hline & 30 & $56.21^{\mathrm{a}}$ & $8186.70^{\mathrm{a}}$ & 1940.4 & $19.44^{\mathrm{a}}$ & $57.84^{\mathrm{a}}$ & $23.91^{\mathrm{b}}$ & $964.88^{\mathrm{a}}$ & $93.81^{\mathrm{a}}$ & $27.11^{\mathrm{a}}$ & $524.01^{\mathrm{ab}}$ \\
\hline \multirow{3}{*}{$\begin{array}{c}\text { Nitrogen } \\
\text { fertilizer }(\mathrm{kg} \\
\left.\mathrm{ha}^{-1}\right)\end{array}$} & 0 & $54.72^{\mathrm{a}}$ & 5 & 1 & $17.17^{\mathrm{b}}$ & $52.79^{\mathrm{b}}$ & $27.45^{\mathrm{a}}$ & $538.02^{\mathrm{c}}$ & $61.88^{\mathrm{b}}$ & $27.33^{\mathrm{ab}}$ & $8^{\mathrm{b}}$ \\
\hline & 50 & $56.25^{\mathrm{a}}$ & $7690.30^{\mathrm{a}}$ & $1946.55^{a}$ & $19.08^{\mathrm{ab}}$ & $55.73^{\mathrm{a}}$ & $25.63^{\mathrm{ab}}$ & $872.65^{\mathrm{b}}$ & $86.75^{\mathrm{ab}}$ & $27.79^{\mathrm{a}}$ & $541.27^{\mathrm{a}}$ \\
\hline & 100 & $55.06^{\mathrm{a}}$ & $8027 . / 4$ & $1993.15^{\mathrm{a}}$ & $19.63^{\mathrm{a}}$ & $57.38^{\mathrm{a}}$ & $24.02^{\mathrm{b}}$ & $981.43^{\mathrm{a}}$ & $100.57^{\mathrm{a}}$ & $26.27^{\mathrm{b}}$ & $523.20^{\mathrm{a}}$ \\
\hline \multirow{2}{*}{$\begin{array}{c}\text { Phosphorus } \\
\text { fertilizer (kg } \\
\left.\mathrm{ha}^{-1}\right)\end{array}$} & 0 & $55.84^{\mathrm{a}}$ & $6733.05^{\mathrm{b}}$ & $1701.28^{b}$ & $17.61^{b}$ & $54.79^{\mathrm{a}}$ & $25.90^{\mathrm{a}}$ & $734.54^{\mathrm{b}}$ & $76.76^{\mathrm{b}}$ & $27.30^{\mathrm{a}}$ & $466.53^{b}$ \\
\hline & 80 & $54.85^{\mathrm{a}}$ & $7636.41^{a}$ & $1910.51^{\mathrm{a}}$ & $19.65^{\mathrm{a}}$ & $55.81^{\mathrm{a}}$ & $25.50^{\mathrm{a}}$ & $860.19^{\mathrm{a}}$ & $90.21^{a}$ & $26.95^{\mathrm{a}}$ & $513.83^{\mathrm{a}}$ \\
\hline
\end{tabular}

Table 5: Mean comparisons for interaction effects of animal manure and nitrogen levels on measured traits in hemp. For fertilization treatments, numbers are means of three replication \pm SEM

\begin{tabular}{|c|c|c|c|c|}
\hline Animal manure $\left(\mathrm{t} \mathrm{ha}^{-1}\right)$ & $\begin{array}{l}\text { Nitrogen fertilizer } \\
\left(\mathrm{kg} \mathrm{ha}^{-1}\right)\end{array}$ & $\begin{array}{l}\text { Biological yield } \\
\quad\left(\mathrm{kg} \mathrm{ha}^{-1}\right)\end{array}$ & Seed yield $\left(\mathrm{kg} \mathrm{ha}^{-1}\right)$ & $\begin{array}{c}\text { Leaf extract yield } \\
\left.\qquad \mathrm{kg} \mathrm{ha}^{-1}\right)\end{array}$ \\
\hline \multirow{4}{*}{0} & 0 & $4522.29 \pm 85.10^{\mathrm{i}}$ & $1159.98 \pm 20.67^{\mathrm{e}}$ & $41.05 \pm 17.23^{\mathrm{f}}$ \\
\hline & 50 & $5992.23 \pm 68.64^{\text {fgh }}$ & $1455.86 \pm 25.51^{\mathrm{cde}}$ & $63.20 \pm 13.14^{\mathrm{def}}$ \\
\hline & 100 & $7061.83 \pm 56.72^{\mathrm{de}}$ & $1718.76 \pm 19.05^{\mathrm{bc}}$ & $75.59 \pm 11.80^{\mathrm{cd}}$ \\
\hline & 0 & $5129.13 \pm 78.41^{\mathrm{hi}}$ & $1273.54 \pm 11.81^{\mathrm{de}}$ & $48.68 \pm 13.25^{\mathrm{ef}}$ \\
\hline \multirow[t]{3}{*}{10} & 50 & $6890.58 \pm 92.57^{\mathrm{def}}$ & $1647.19 \pm 30.48^{c}$ & $68.93 \pm 13.81^{\mathrm{cde}}$ \\
\hline & 100 & $7786.29 \pm 86.14^{\text {cd }}$ & $1710.48 \pm 29.07^{\mathrm{c}}$ & $87.93 \pm 14.09^{b c}$ \\
\hline & 0 & $5848.32 \pm 65.88^{\mathrm{gh}}$ & $1519.01 \pm 23.02^{\mathrm{cd}}$ & $57.30 \pm 10.26^{\text {def }}$ \\
\hline \multirow[t]{3}{*}{20} & 50 & $8562.79 \pm 86.22^{\mathrm{bc}}$ & $2034.00 \pm 31.75^{\mathrm{ab}}$ & $101.98 \pm 16.79^{\mathrm{ab}}$ \\
\hline & 100 & $9563.08 \pm 120.53^{\mathrm{a}}$ & $2130.54 \pm 29.25^{\mathrm{a}}$ & $122.67 \pm 19.96^{\mathrm{a}}$ \\
\hline & 0 & $6453.02 \pm 90.05^{e^{e f g}}$ & $1559.47 \pm 32.94^{\text {cd }}$ & $63.06 \pm 11.45^{\text {def }}$ \\
\hline \multirow[t]{2}{*}{30} & 50 & $9315.63 \pm 52.46^{\mathrm{ab}}$ & $2085.84 \pm 19.64^{\mathrm{a}}$ & $115.57 \pm 12.98^{\mathrm{a}}$ \\
\hline & 100 & $8396.21 \pm 121.13^{\mathrm{bc}}$ & $1728.82 \pm 30.54^{\mathrm{bc}}$ & $106.36 \pm 29.36^{\mathrm{ab}}$ \\
\hline
\end{tabular}

In each column, the values that share at least one letter have no significant differences according to LSD test at 5 percent of probability.

increased, although there was not a significant difference between of 20 and $30 \mathrm{t} \mathrm{ha}^{-1}$ manure (Figure 1).

With the use of 20 and $30 \mathrm{t} \mathrm{ha}^{-1}$ manure, the grain mass increased by 11.44 and $11.26 \%$, respectively, com- pared to the control. The most beneficial effect of manure was achieved in the range of 10 to $20 \mathrm{tha}^{-1}(0.11 \mathrm{~g}$ per ton of manure, on average), although the more increase in manure reduced the effectiveness of manure on seed 
mass (Table 4). The application of $100 \mathrm{~kg} \mathrm{~N} \mathrm{ha}^{-1}$ increased the seed mass by $14.27 \%$ compared with the control. Despite the increase of the seed mass under the influence of the nitrogen, the results indicated that the average effectiveness of nitrogen on the seed mass in the range of 0 to $50 \mathrm{~kg} \mathrm{~N} \mathrm{ha}^{-1}\left(0.04 \mathrm{~g}\right.$ per $\left.\mathrm{kg} \mathrm{N} \mathrm{ha}^{-1}\right)$, was more than 50 to $100 \mathrm{~kg} \mathrm{~N} \mathrm{ha}^{-1}$ (0.01 g per kg N ha ${ }^{-1}$ ) (Table 4).

Based on a linear relationship, an increase in the leaf harvest index in hemp was consistent with decreasing the seed harvest index (Figure 2). The application of manure was effective in increasing the leaf harvest index and the levels of 20 and $30 \mathrm{t} \mathrm{ha}^{-1}$ manure, compared to the control, increased the leaf harvest index by 7.5 and $9.62 \%$, respectively. However, the use of $30 \mathrm{t} \mathrm{ha}^{-1}$ of manure reduced the seed harvest index by $8.87 \%$, as compared with the control (Table 4). Thus, it seems applying $30 \mathrm{t}$ ha- 1 of manure stimulate assimilate partitioning to plant leaves and thereby reduced allocation ratio to seeds.

It is worth noting that the use of nitrogen fertilizer in hemp also increased the leaf harvest index, as 50 and $100 \mathrm{~kg} \mathrm{~N} \mathrm{ha}^{-1}$ increased this index by 5.56 and $8.7 \%$, respectively, compared with the control treatment, while using $100 \mathrm{~kg} \mathrm{~N} \mathrm{ha}^{-1}$ resulted in a $12.49 \%$ reduction in the seed harvest index, compared to its non-application (Table 4). So, like the highest level of manure, the level of 100 $\mathrm{kg} \mathrm{N} \mathrm{ha}^{-1}$ reduced allocation of assimilates to the seeds by more biomass partitioning to the plant leaves.

The highest and the lowest leaf extract yields were obtained with integrated application of $20 \mathrm{t}$ ha-1 manure with $100 \mathrm{~kg} \mathrm{~N} \mathrm{ha}^{-1}$ and in no-fertilizer treatment, respectively (Table 5). The use of nitrogen alone (without manure) reduced the efficiency of nitrogen in increasing the yield of leaf extract, as in the ranges of 0-50 and 50-100 $\mathrm{kg} \mathrm{N} \mathrm{ha}^{-1}$, the average yield of hemp leaf extract increased by 0.44 and $0.27 \mathrm{~kg}$ per $\mathrm{kg} \mathrm{N}$ applied, respectively. These values were 0.40 and $0.38 \mathrm{~kg}$ leaf extract per $\mathrm{kg} \mathrm{N}$ applied for the level of $10 \mathrm{t} \mathrm{ha}^{-1}$ manure and 0.89 and $0.41 \mathrm{~kg}$ leaf extract per $\mathrm{kg} \mathrm{N}$ applied for the level of $20 \mathrm{t} \mathrm{ha}^{-1}$ manure, respectively. With $30 \mathrm{t} \mathrm{ha}^{-1}$ manure, the leaf extract yield increased by $1.05 \mathrm{~kg}$ per $\mathrm{kg} \mathrm{N}$ applied in the range of 0-50 $\mathrm{kg} \mathrm{N}$ ha-1, while it decreased by $0.18 \mathrm{~kg}$ per $\mathrm{kg} \mathrm{N}$ applied from 50 to $100 \mathrm{~kg} \mathrm{~N} \mathrm{ha}^{-1}$ (Table 5). The results suggested that at all levels of manure, the effectiveness of nitrogen on the leaves extract yield was more in the first $50 \mathrm{~kg}$ than that of the second one. The combination of the highest levels of manure and nitrogen had a negative effect on the yield of hemp leaf extract.

There was a relation between yield of hemp leaf extract with specific leaf area (SLA), as an increase in the manure level reduced the SLA and increased the yield of leaf extract. Further, the SLA of most treatments was in the range of 20 to $40 \mathrm{~cm}^{2} \mathrm{~g}^{-1}$. (Figure 3).

The 20 and $30 \mathrm{t} \mathrm{ha}^{-1}$ manure increased seed extract yield by 48.33 and $41.02 \%$, respectively, in comparison with the non-application of manure (Table 4). The level of $20 \mathrm{t} \mathrm{ha}^{-1}$ of manure was the most effective in increasing the yield of seed extract, since the yield of seed extract increased by 16.55 and $31.74 \mathrm{~kg} \mathrm{t}^{-1}$ manure applied in the range of 0-10 and 10-20 $\mathrm{tha}^{-1}$ manure, respectively. Nevertheless, the yield of seed extract was reduced by $8.73 \mathrm{~kg}$ $\mathrm{t}^{-1}$ manure applied from 20 to $30 \mathrm{t} \mathrm{ha}^{-1}$ manure (Table 4).

Seed extract yield increased in response to higher nitrogen fertilizer levels, so applying 50 and $100 \mathrm{~kg} \mathrm{~N} \mathrm{ha}^{-1}$ increased the seed extract yield by 40.19 and $62.52 \%$, compared to the control (non-application of nitrogen), respectively (Table 4 ). The positive effect of nitrogen utility on seed extract yield decreased by increasing the nitrogen levels, so the amount of increase in the seed extract per nitrogen consumed in the range of $0-50 \mathrm{~kg} \mathrm{~N}$ $\mathrm{ha}^{-1}$ (0.5 kg kg-1 nitrogen) was more than that of $50-100$ $\mathrm{kg} \mathrm{N} \mathrm{ha}^{-1}$ (0.28 $0.5 \mathrm{~kg} \mathrm{~kg}^{-1}$ nitrogen) (Table 4).

The use of manure led to higher seed oil percentage,

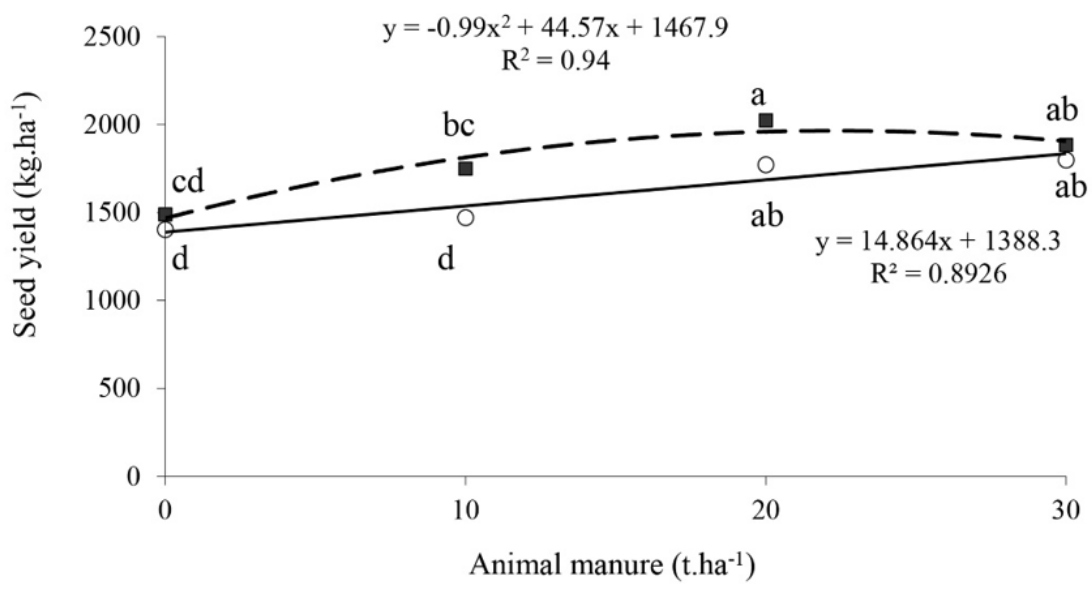

Figure 1: Response of hemp seed yield to animal manure at $0(\mathrm{O})$ and $80(\mathbf{\square}) \mathrm{kg} \mathrm{P} \mathrm{ha}^{-1}$. The points that share at least one letter have no significant differences according to FLSD test at 5 percent of probability. 


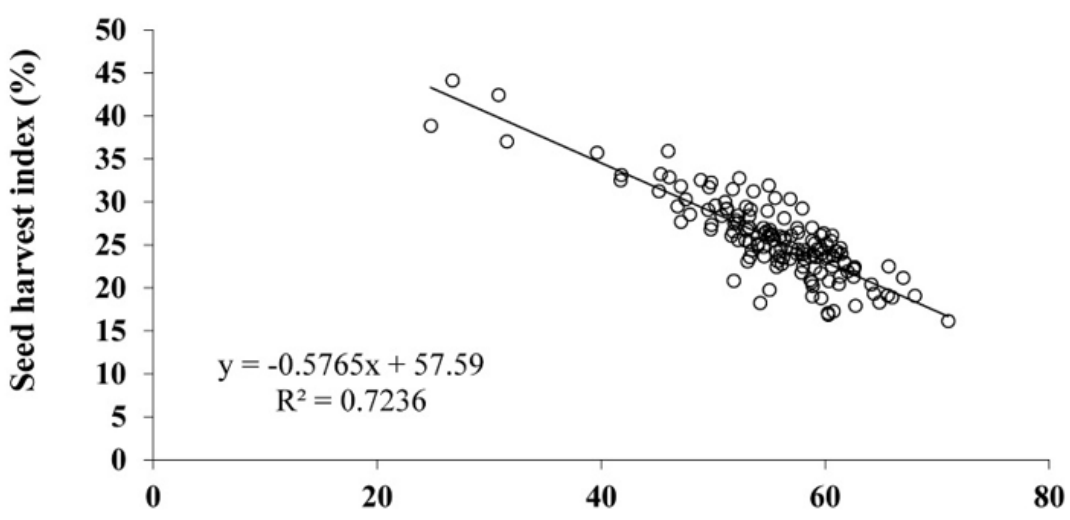

Leaf harvest index $(\%)$

Figure 2: Changes of seed harvest index (\%) to leaf harvest index (\%) in hemp.

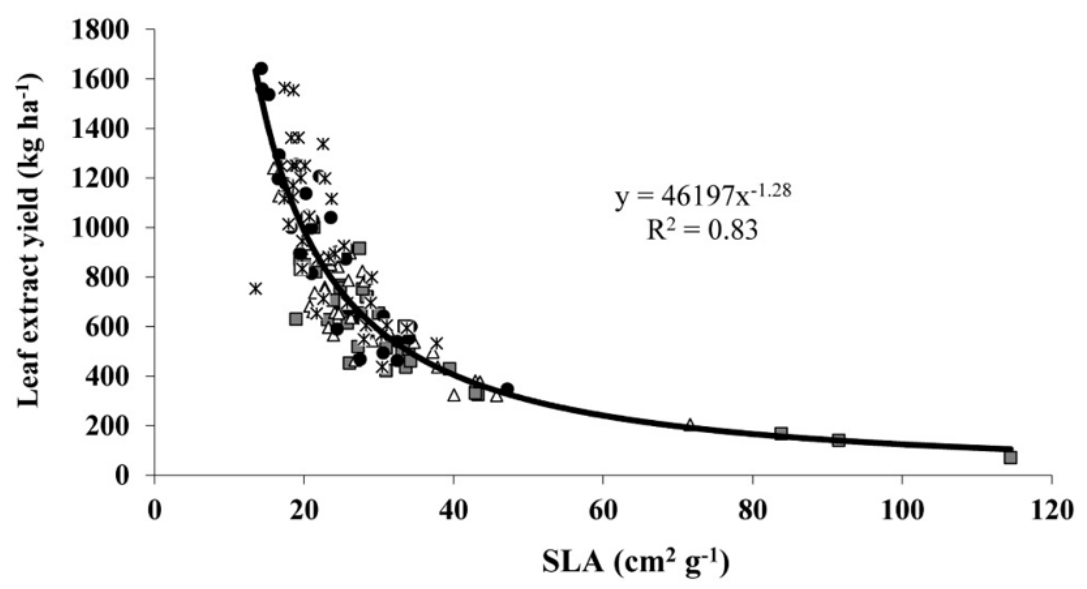

Figure 3: Changes of Leaf extract yield $\left(\mathrm{kg} \mathrm{ha}^{-1}\right)$ to SLA $\left(\mathrm{cm}^{2} \mathrm{~g}^{-1}\right)$ for $0(\mathbb{\bullet}), 10(\triangle), 20(\bullet)$ and $30(*)$ ton animal manure ha ${ }^{-1}$

so that applying 10,20 , and $30 \mathrm{tha}^{-1}$ of manure increased seed oil by $10.58 \%, 8.38 \%$ and $6.23 \%$, respectively, compared to the control. An increase in manure level by more than $10 \mathrm{tha}^{-1}$ decreased the profitability of manure to increase the percentage of seed oil (Table 4).

The highest percentage of seed oil $(28.85 \%)$ was achieved by applying $50 \mathrm{~kg} \mathrm{~N}^{-1}$ and not using phosphorus (Figure 4). When no phosphorus was used, an increase in the nitrogen levels up to $50 \mathrm{~kg} \mathrm{~N} \mathrm{ha}^{-1}$ improved its efficiency to enhance the seed oil percentage, although efficiency was reduced with more nitrogen consumption, so that, in the absence of phosphorus application, the level of $100 \mathrm{~kg} \mathrm{~N} \mathrm{ha}^{-1}$ decreased the percentage of seed oil by $4.77 \%$, compared to the $50 \mathrm{~kg} \mathrm{~N} \mathrm{ha}^{-1}$. When phosphorus was used, the nitrogen effectiveness on the seed oil percentage decreased by increasing its level, however there was not any significant differences between 50 and 100 $\mathrm{kg} \mathrm{N} \mathrm{ha}{ }^{-1}$ with in terms of seed oil percentage (Figure 4).

The slopes of regression lines fitted between the oil yields versus the seed yields were significant $(p \leq 0.01)$, indicating any increase in the seed yield is accompanied with the oil yield, the use of manure, especially at levels of 10 and $20 \mathrm{tha}^{-1}$ (compared with control), was more effective in increasing the yield of oil than grain yield (Figure 5).All levels of manure were effective in increasing the yield of seed oil as 10, 20 and $30 \mathrm{tha}^{-1}$ of manure increased the seed oil yield by $22.82 \%, 41.81 \%$, and $33 \%$, respectively, compared to the control. Compared to the application of $20 \mathrm{t} \mathrm{ha}^{-1}$ of manure, the $30 \mathrm{t} \mathrm{ha}^{-1}$ manure caused a slight and non-significant decline in seed oil yield (Table 4 ).

The 50 and $100 \mathrm{~kg} \mathrm{~N} \mathrm{ha}^{-1}$ levels improved the seed oil yield by 33.30 and $28.84 \%$, respectively, compared to 
the control and with the application of $100 \mathrm{~kg} \mathrm{~N} \mathrm{ha}^{-1}$ the yield of the hemp seed oil showed a slight and non-significant decrease (Table 4).

The consumption of $80 \mathrm{~kg} P$ ha- 1 increased the biological yield (13.41 \%), seed mass (11.6\%) and the seed oil yield (10.13\%), compared to the control (no phosphorus application) (Table 4). The results also indicated that the phosphorus improved the yield of leaf and seed extracts by 17.9 and $17.52 \%$, respectively. The phosphorus was more effective in increasing the leaf extract yield than seed extract, so that phosphorus increased the yield of leaf and seed extracts by 1.57 and $0.17 \mathrm{~kg}$ per $\mathrm{kg} \mathrm{P}$, respectively (Table 4).

\subsection{DISCUSSION}

In this experiment, the effect of year on the measured traits was not significant (Table 4). The average temperature for the cropping seasons was approximately the same for two years (the average temperature in 2013 and 2014 was 22.66 and $23.96^{\circ} \mathrm{C}$, respectively) (Table 1). A little superiority which was observed in 2014 in some measured traits, such as the seed yield, seed mass, leaf and seed harvest indices, the yields of seed and plant oil extracts, is probably due to more suitable germination temperature in this year compared to 2013. The optimum temperature for germination of hemp seeds is 20 ${ }^{\circ} \mathrm{C}$ (Albu and Marti, 2008) and the lower temperature in May $2014\left(22.3^{\circ} \mathrm{C}\right)$, compared to the June 2013 (26.7 ${ }^{\circ} \mathrm{C}$, Table 1), which are the planting times in this experiment, caused germination and early growth of the plant in 2014 to be occurred in a more appropriate condition. The more rainfall in June and October 2014, compared to

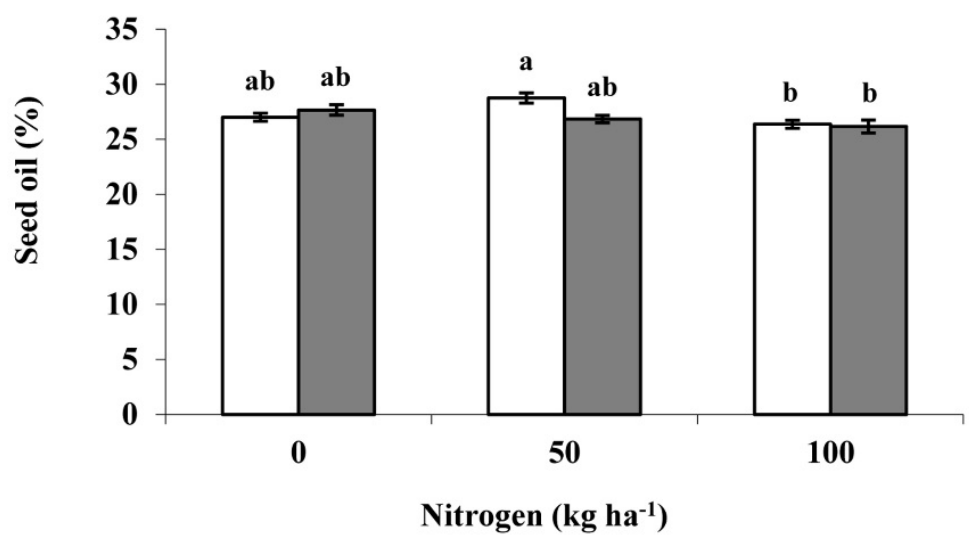

Figure 4: Response of hemp seed oil percentage to applied nitrogen at 0 (white columns) and 80 (dark columns) $\mathrm{kg} \mathrm{P}^{\mathrm{P}} \mathrm{g}^{-1}$. The columns that share at least one letter have no significant differences according to FLSD test at 5 percent of probability. Vertical bars on columns indicate SEM.

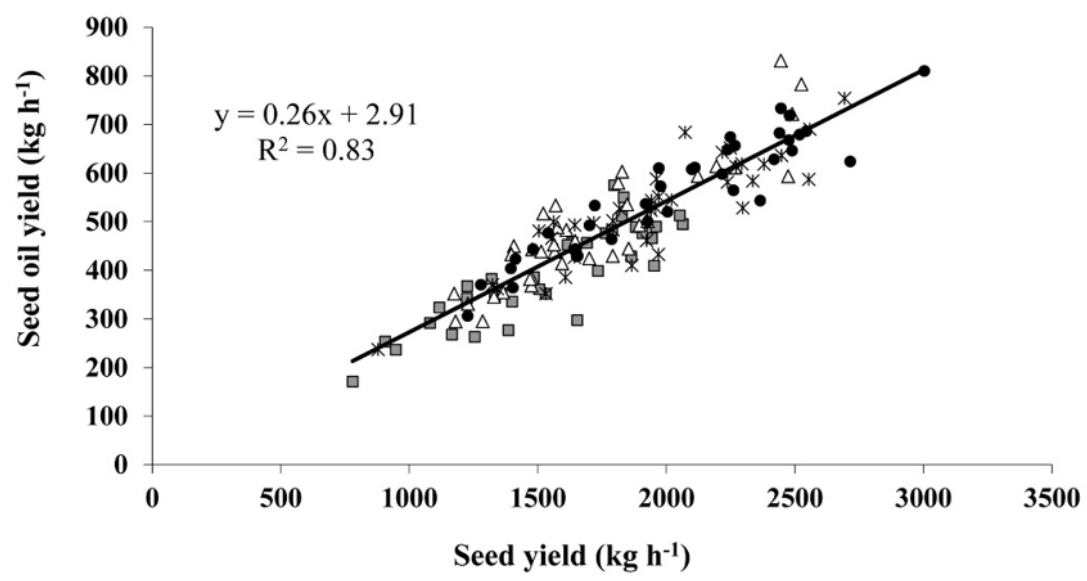

Figure 5: Changes of seed oil yield $\left(\mathrm{kg} \mathrm{ha}^{-1}\right)$ to seed yield $\left(\mathrm{kg} \mathrm{ha}^{-1}\right)$ for $0(\mathbf{\square}), 10(\triangle), 20(\mathbf{O})$ and $30(*)$ ton animal manure ha-1 
2013, was also effective in improving the measured traits in this year (Table 1). Also the higher soil EC of the experimental site in 2013 could be one of the reasons for the overall decline in traits in this year compared to 2014 (Table 2).

Chemical agents and environmental parameters have been identified are among the factors affecting the expression of sex genes in hemp (Milewicz and Sawicki, 2012). Nitrogen is more or less effective on incidence of male sex in hemp (Truta et al., 2007); but to increase the female sex ratio in population, it is necessary to increase the nitrogen level (Hall et al., 2013). Generally, in this study, an increase in the levels of manure and nitrogen slightly increased the percentage of female plants, compared to their control; which was not significant (Table 4 ). This is probably due to the use of moderate levels of nitrogen fertilizer in integration with manure application, and the effect of these moderate levels of fertilizers on increasing female sex in hemp. The use of phosphorus reduced the percentage of female plants in hemp, although its effect was not significant in this study (Table 4). In an experiment on sweet gale (Myrica gale L.), the application of phosphorus also reduced the abundance of female plants (Chang and Martin, 2014).

The increase of the biological, seed, and leaf extract yields under the combined effect of manure and the nitrogen fertilizer, compared to the application of manure alone, indicated the synergistic effect of manure and nitrogen (Table 5). The increase of plant yield in the integrated system of plant nutrition is due to the availability of the soil nitrogen when needed by plant. When chemical and organic fertilizers are used in combination with each other, the nutrients in the chemical fertilizers are quickly released and help the initial establishment of the plant. On the contrary the mineralization of organic fertilizer is gradually done during the growing season, which helps to achieve higher plant yields (Ayoola et al., 2007). More than 70 nitrogenous compounds, including alkaloids, amides, lignanamide and proteins (edestin, zeatin and zeatin nucleoside), enzymes (edestinase, glucosidase, polyphenoloxydase, peptidase, peroxidase and adenosine-5-phosphatase), and amino acids have been recognized in hemp (Bernneisen, 2007). The synthesis of these nitrogenous compounds existent in the hemp extract is influenced by the amount of nutrients absorbed by the plant, especially nitrogen.

The combined application of $30 \mathrm{t} \mathrm{ha}^{-1}$ of manure, with high levels of nitrogen had a negative effect on biological and seed yields (Table 5). In fact, adding manure was effective in increasing nitrogen absorption by plants. Despite the higher levels of phosphorus compared to the nitrogen in the most manures, plants absorb nitrogen about 2.4 to 4.5 times more than the phosphorus through animal manures (Mullins, 2009). The pools of nitrogen absorbed through the manure or chemical fertilizers by the plant, as protein or amino acids, requires carbon inputs to provide the structure of the carbon skeleton and energy supply (Cheng et al., 2004) and this can reduce the growth and yield of the plant. The nitrogen has a complex effect on the metabolism of plant carbohydrates. Sometimes it significantly increases the production of carbohydrates and in some cases reduces it significantly (Murata, 1969). Nitrogen requires some metabolites of Krebs cycle to stabilize amino acids. The continuation of this cycle involves the use of carbohydrates and their derivatives. The reduction of nitrite and nitrate also requires a reducing power derived from photosynthesis and respiration. If this power is provided through respiration, it will reduce plant's carbohydrates and, if it is provided through the photosynthesis, a less amount of $\mathrm{CO}_{2}$ is reduced and converted to carbohydrates (Minotti et al., 1969).

Based on the results, an increase in the levels of manure and nitrogen increased the leaf harvest index, while the seed harvest index decreased significantly at 30 $\mathrm{t} \mathrm{ha}^{-1}$ manure and also $100 \mathrm{~kg} \mathrm{~N} \mathrm{ha}^{-1}$, compared to their controls (Table 4). Thus, it seems that the high levels of manure and nitrogen disturb the partitioning balance between leaves and seeds of hemp plant by further allocation to leaves and thus stimulated the vegetative growth of the plant. However, when lower levels of manure or nitrogen were applied, a more balanced trend was observed in assimilates partitioning between the seed and the leaf. Maobe et al. (2010) also reported that the effect of nitrogen on increasing the photosynthesis rate in vegetative parts of the plant was effective in increasing dry matter accumulation and the ratio of vegetative parts to the plant seed and accordingly, reducing the seed harvest index. The existence of a negative and high correlation between the leaf harvest index and the seed yield index $(\mathrm{r}=-0.851, p<0.01)$ suggests that an increase in assimilates allocation to the leaf does not necessarily lead to an increase in biomass partitioning to the seed at the reproductive stage in the hemp (Figure 2).

It seems that the addition of phosphorus fertilizer to the manure, up to $20 \mathrm{t} \mathrm{ha}^{-1}$, has a positive effect on supplying the nutrient requirements of plant, especially the phosphorus, and increases the seed yield. Applying more manure may diminish the positive effect of phosphorus fertilizer because the plant's needs have already been achieved (Figure 1). The results of manure analysis revealed high levels of phosphorus in manure in both years of the experiment (Table 2). Therefore, manure seems to be effective in supplying phosphorus needed by the plant. Generally, it is not necessary to use higher fertilizer (a combined application of $30 \mathrm{t} \mathrm{ha}^{-1}$ with $80 \mathrm{~kg}$ 
$\mathrm{P} \mathrm{ha}^{-1}$ ) to increase grain yield and even cause loss of fertilizer and increase the cost of fertilizer supply. Through the application of soluble forms of phosphorus (e.g. triple superphosphate), the $\mathrm{P}$ ions reacts with $\mathrm{Ca}, \mathrm{Fe}$ or $\mathrm{Al}$ ions, and then may convert to an insoluble form, or adsorb on clay particles in the soil. In this regard, the use of animal manure may be a better source to supply plant's phosphorus needs. The manures can store phosphorus in their adsorption sites and provide plants with its soluble forms during growth season. Because of this, using animal manures is recommended in acidic and calcareous soils for optimal supply of phosphorus required by the plants (Abolfazli et al., 2010).

The seed mass showed a positive reaction to application of manure, nitrogen, and phosphorus fertilizers (Table 4). Increasing seed mass is one of the effective factors in increasing the seed yield (Akongwubel et al., 2012). Further, a positive and significant correlation was observed between the seed mass and the seed yield $(0.424, p<0.01)$ in this study. In another study on isabgol (Plantago ovata Forsk), an increase in seed mass and seed yield were reported by adding organic matter (Yadav et al., 2002). In fact, the seed mass is determined during its filling period, and providing sufficient photosynthetic materials at this stage, reduces the competitive effect of seeds to get these materials, which is effective in increasing the seeds mass (Reed et al., 1988).

Increasing the level of manure, especially at the levels of 20 and $30 \mathrm{tha}^{-1}$, was effective in increasing the yield of leaf extract and hemp seed (Table 4). The highest leaf extract yield was obtained in the combined treatment of $20 \mathrm{t} \mathrm{ha}^{-1}$ manure along with $100 \mathrm{~kg} \mathrm{ha}^{-1}$ nitrogen (Table 5). The leaf and seed extract yield had the highest correlation with the biological $(0.915, p<0.01)$ and seed yield $(0.771$, $p<0.01)$, respectively. It seems that the leaf extract yield was more sensitive to adding nitrogen fertilizer than seed extract yield. While the application of $50 \mathrm{~kg} \mathrm{ha}^{-1}$ nitrogen significantly increased the yield of hemp leaf extract, a significant increase in the yield of seed extract was obtained by using $100 \mathrm{~kg} \mathrm{ha}^{-1}$ nitrogen (Table 4).

By increasing the level of manure, SLA decreased and the yield of leaf extract increased (Figure 3). In other words, with decreasing SLA, leaf thickness increased (Dantas et al., 2017), and the synthesis of effective compounds in the extract of hemp leaves increased by increasing leaf dry mass (compared to leaf area).

In this experiment, with an increase in manure levels in excess of $10 \mathrm{t} \mathrm{ha}^{-1}$, the rate of increase in seed oil decreased (Table 4 ). The highest seed and oil yield was obtained at $20 \mathrm{t} \mathrm{ha}^{-1}$. The use of $20 \mathrm{t} \mathrm{ha}^{-1}$ of manure (compared to $10 \mathrm{t} \mathrm{ha}^{-1}$ of this fertilizer), increased grain yield more than reducing the percentage of seed oil, which increased the yield of seed oil (Table 4).
It seems that low nitrogen levels are necessary to increase the oil content and higher levels of this fertilizer, reduce the percentage of seed oil (Table 4). The reaction of the seed oil content to nitrogen was different in the case of application and non-application of phosphorus. With the application of phosphorus, the reaction of seed oil content decreased to nitrogen. In the absence of phosphorus application, consumption of $50 \mathrm{~kg} \mathrm{~N} \mathrm{ha}^{-1}$ increased and application of $100 \mathrm{~kg} \mathrm{~N} \mathrm{ha}^{-1}$ of this fertilizer reduced the content of seed oil (Figure 4 ). The higher nitrogen absorption under phosphorus treatment increases the nitrogen content of plant (Graciano et al., 2006) and consequently reduces the percentage of seed oil, because the amount of carbohydrates needed to synthesize the protein is less than oil. Therefore, with the use of nitrogen, more carbohydrates are used to synthesize amino acids and proteins, and consequently the synthesis of fatty acids and oils are reduced (Rathke et al., 2005). On the other hand, the results of this experiment indicated the main effect of phosphorus on reducing the oil content, although no significant difference was observed (Table 4).

The high correlation coefficient of the oil yield with the seed yield $(0.913, p<0.01)$ revealed that the oil yield was more affected by seed yield, compared to the oil content, it had less effect. In other words, an increase in the seed yield, increased the oil yield. In the other studies also a positive and significant correlation was observed between the oil yield and the seed yield (Basalma, 2007; Marjanovic-Jeromela et al., 2008; Flajšman et al., 2019). It seems that with application of $100 \mathrm{~kg} \mathrm{ha}^{-1}$ nitrogen, the seed oil content was decreased compared to control treatment, but a $35.12 \%$ increase in seed yield, compensated the reduction of oil percent and increased the oil yield (Table 4). In this experiment, the application of phosphorus and $100 \mathrm{~kg} \mathrm{ha}^{-1}$ nitrogen was effective in increasing the oil and biological yield of hemp. Based on the results of Rajesware Rao et al. (1989), the application of phosphorus and $100 \mathrm{~kg} \mathrm{ha}^{-1}$ nitrogen was effective in increasing oil and biomass yield of the Artimisia pallens Wall. ex DC.. Despite the slight reduction in the percentage of seed oil due to the consumption of phosphorus, the oil yield increased because of increasing seed yield of the plant (Table 4). Phosphorus can increase the oil content of plants by increasing the photosynthesis and the enzyme activity (Mohammadi et al., 2013).

\section{CONCLUSIONS}

The results suggested that adjusting the amount of organic and chemical fertilizers are important, depending on the purpose of the application for planting hemp. The combined application of $20 \mathrm{t} \mathrm{ha}^{-1}$ of manure along 
with $100 \mathrm{~kg} \mathrm{ha}^{-1}$ of nitrogen, produced the highest biological, seed and leaf extract yield. In order to increase the yield of seed oil, $20 \mathrm{tha}^{-1}$ manure, as well as $100 \mathrm{~kg}$ $\mathrm{ha}^{-1}$ of nitrogen is suitable and the application of higher amounts of fertilizer will increase costs and waste of fertilizer. In conclusion, given that the applied manure adds some nutrients to the soil that can be made available to the plant, it seems that hemp to respond well to nitrogen supplied by the combined use of chemical and animal fertilizers, in while its response to phosphorus fertilization is limited. Therefore, the application of animal manure not only reduces the need for chemical fertilizers consumption by satisfying part of the plant demand for nitrogen, but also has positive effects on improving soil properties, and therefore combined application of manure and chemical fertilizers is strongly recommended for the sustainability of cannabis planting systems.

\section{REFERENCES}

Abolfazli, F., Forghani, A. and Norouzi, M. (2012). Effects of phosphorus an organic fertilizers on phosphorus fractions in submerged soil. Journal of Soil Science and Plant Nutrition, 12, 349-362. https://doi.org/10.4067/S071895162012000200014.

Akande, M. O., Oluwatoyinbo, F. I., Makinde, E. A., Adepoju, A. S., and Adepoji I. S. (2010). Response of okra to organic and inorganic fertilization. Nature and Science, 8(11), 261266. https://doi.org/10.7537/marsnsj081110.33

Akbari, P., Ghalavand, A., Modarres Sanavy, A. M., and Agha Alikhani, M. (2011). The effect of biofertilizers, nitrogen fertilizer and farmyard manure on grain yield and seed quality of sunflower (Helianthus annuus L.). International Journal of Agricultural Technology, 7(1), 173-184. (http://www.ijataatsea.com/pdf/January_v7_n1_11/17-IJAT2010_21R.pdf)

Akongwubel, A. O., Ewa, U. B., Prince, A., Jude, O., Martins, A., Simon, O., and Nicholas O. (2012). Evaluation of agronomic performance of maize (Zea mays L.) under different rates of poultry manure application in an ultisol of Obubra, Cross River State, Nigeria. International Journal of Agriculture and Forestry, 2(4), 138-144. https://doi.org/0.5923/j. ijaf.20120204.01

Albu, S. G., and Marti, R. 2008. Effect of germination on hemp (Cannabis sativa L.) seed composition. Acta Universitatis Cibiniensis. Series E: Food Technology, 12(2), 27-34. (http://saiapm.ulbsibiu.ro/cercetare/ACTA_E/AUCFT\%20 2008II\%2027_34.pdf).

Amanulla, A., Hassan, M. J., Nawab, K., and Ali. A. (2007). Response of specific leaf area (SLA), leaf area index (LAI) and leaf area ratio (LAR) of maize (Zea mays L.) to plant density, rate and timing of nitrogen application. World Applied Sciences Journal, 2(3), 235-243. (https://pdfs.semanticscholar. org/d603/df91ae657d170f318717ea8fffec841e82d4.pdf).

Amiri, M. E. (2009). Comparison of animal manures and chemical fertilizers on saffron (Crocus sativus L.) cultivation. In The Proceedings of the International Plant Nutrition
Colloquium XVI. UC Davis: Department of Plant Sciences. Retrieved from https://escholarship.org/uc/item/14d581t5 Arif, M., Ali, K., Jan, M.T., Shah, Z., Jones, D. L., and Quilliam, R. S. (2016). Integration of biochar with animal manure and nitrogen for improving maize yields and soil properties in calcareous semi-arid agroecosystems. Field Crop Research, 195, 28-35. https://doi.org/10.1016/j.fcr.2016.05.011

Association of Official Analytical Chemists (AOAC). (1990). Official Methods of Analysis of the AOAC. 15th ed. Arlington, VA, USA: Association of Official Analytical Chemists.

Ayoola, O. T., and Adeniyan, O. N. (2006). Influence of poultry manure and NPK fertilizer on yield and yield components of crops under different cropping systems in south west Nigeria. African Journal of Biotechnology, 5(15), 1386-1392. (https://www.ajol.info/index.php/ajb/article/ view/43121/26666)

Basalma, D. (2008). The correlation and path analysis of yield and yield components of different winter rapeseed (Brassica napus L.) cultivars. Research Journal of Agriculture and Biological Sciences, 4(2), 120-125. (http://www.aensiweb.net/ AENSIWEB/rjabs/rjabs/2008/120-125.pdf).

Baranauskienne, R., Venskutonis, P. R., Viskelis, P., and Dambrausiene, E. (2003). Influence of nitrogen fertilizer on the yield and composition of thyme (Thymus vulgaris). Journal of Agricultural and Food Chemistry, 51(26), 7751-7758. https://doi.org/10.1021/jf0303316

Bernneisen, R. (2007). Chemistry and analysis of phytocannabinoids. In M. A. Elsohly (Ed.), Marijuana and the Cannabinoids (pp. 29-30). Totowa, New Jersey: Human Press Inc.

Bouyoucos, G. J. (1951). A recalibration of hydrometer method for making mechanical analysis of soil. Agronomy Journal, 43, 434-438. https://doi.org/10.2134/agronj1951.00021962 $004300090005 \mathrm{x}$

Chang, X., and Martin, P. (2014). N, P and K fertilizers alter plant growth, essential oil yield and gender of sweet Gale (Myrica gale L). The Open Plant Science Journal, 8, 9-17. https://doi.org/10.2174/1874294720140708003

Cheng, L., Ma, F., and Ranwala, D. (2004). Nitrogen storage and its interaction with carbohydrates of young apple trees in response to nitrogen supply. Tree Physiology, 24, 91-98. https://doi.org/10.1093/treephys/24.1.91

Cvetkov, M., Šantavec, I., Kocjan Ačko, D., and Tajnšek, A. (2010). Soil organic matter content according to different management system within long-term experiment. Acta Agriculturae Slovenica, 95, 79-88. (http://aas.bf.uni-lj.si/ februar2010/11cvetkov.pdf).

Dadkhah, A. (2012). Effect of chemicals and bio-fertilizers on yield, growth parameters and essential oil contents of funnel (Foeniculum vulgare Miller.). Journal of Medicinal Plants and By-products (JMPB). 1(2), 101-105. (http://jmpb.areeo. ac.ir/article_108473_dce8e9b584798e5da0eec7f7c584dcca. pdf)

Dantas, M. S. M., Rolim, M. M., Pedrosa, E. M. R., Silva, M. M. D. S., and Dantas, D. D. C. (2017). Growth and seed yield of sunflower on soil fertilized with Cassava wastewater. Revista Caatinga, 30(4), 963-970. https://doi.org/10.1590/1983$21252017 \mathrm{v} 30 \mathrm{n} 417 \mathrm{rc}$

Da Porto, C., Decorti, D., and Natolino, A. (2014). Ultrasoundassisted extraction of volatile compounds from industrial 
Cannabis sativa L. inflorescences. International Journal of Applied Research in Natural Products, 7, 8-14. (http://www. ijarnp.org/index.php/ijarnp/article/view/228/pdf_18).

Esmaeilian, Y., Nouri, H., Amiri, E., Mashhadi Akbar Boojar, M., Babaeian, M., and Tavassoli, A. (2011). Investigation the influences of manure sources and chemical fertilizers on yield, protein and oil content of sunflower under drought stress. Australian Journal of Basic and Applied Sciences, 5(10), 1084-1089. (http://www.ajbasweb.com/old/ ajbas/2011/October-2011/1084-1089.pdf).

Fathordoobady, F., Singh, A., Kitts, D. D., and Pratap Singh, A. (2019). Hemp (Cannabis sativa L.) extract: anti-microbial properties, methods of extraction, and potential oral delivery. Food Reviews International, 35(7), 664-684. https://doi. org/10.1080/87559129.2019.1600539

Faux, A. M., Draye, X., Lambert, R., d'Andrimont, R., Raulier, P., and Bertin, P. (2013). The relationship of stem and seed yields to flowering phenology and sex expression in mooecious hemp (Cannabis sativa L.). European Journal of Agronomy, 47, 11-23. https://doi.org/10.1016/j.eja.2013.01.006

Flajšman, M., Šantavec, I., Kolmanič, A., Košmelj, K., and Kocjan-Ačko, D. (2019). Agronomic performance and stability of seed, protein and oil yields of seven soybean cultivars determined in field experiments in Slovenia. Genetika, 51(1), 31-46. https://doi.org/10.2298/GENSR1901031F

Ghosh, P. K., Ramesh, P., Bandyopadhay, K. K., Tripathi, A. K., Hati, K. M., and Misra, A. K. (2004). Comparative effectiveness of cattle manure, poultry manure, phosphocompost and fertilizer-NPK on three cropping systems in vertisoils of semi-arid tropics. I. Crop yields and systems in performance. Bioresource Technology, 95, 77-83. https://doi. org/10.1016/j.biortech.2004.02.011

Graciano, C., Goya, J. F., Frangi, J. L., and Guiament, J. J. (2006). Fertilization with phosphorus increases soil nitrogen absorption in young plants of Eucalyptus grandis. Forest Ecology and Management, 236(2-3), 202-210. https://doi. org/10.1016/j.foreco.2006.09.005

García-Tejero, I. F., Durán-Zuazo, V. H., Pérez-Álvarez, R., Hernández, A., Casano, S., Morón, M., and Muriel-Fernández, J. L. (2014). Impact of plant density and irrigation on yield of hemp (Cannabis sativa L.) in a Mediterranean semi-arid environment. Journal of Agricultural Science and Technology, 16(4), 887-895. (http://jast.modares.ac.ir/article-23-9987-en.pdf).

Hall, J., Bhattarai, S. P., and Midmore, D. J. (2013). Review of flowering control in industrial hemp. Journal of Natural Fibers 9(1), 23-36. https://doi.org/10.1080/15440478.2012. 651848

Hendawy, S. F., El-Sherbeny, S. E., El-Razik, T. M., Hagazy, M. H., and Hussein, M. S. (2014). Effect of NP fertilization on growth and essential oil of lovage plants under Egyptian conditions. Middle East Journal of Agriculture Research, 3(4), 1031-1036.

Hendawy, S. F., and Khalid, Kh. A. (2011). Effect of chemical and organic fertilizers on yield and essential oil of chamomile flower heads. Medicinal and Aromatic Plant Science and Biotechnology 5(1): 43-48. (http://www.globalsciencebooks. info/Online/GSBOnline/images/2011/MAPSB_5(1)/ MAPSB_5(1)43-48o.pdf).
Hoffman, G., and Cleemput, O. (2004). Soil and Plant Nitrogen. 1st ed. Paris, France: International Fertilizer Industry Association.

Jackson, M. L. (1958). Soil Chemical Analysis. 1st ed. Englewood Cliffs, New Jersey, USA: Prentice- Hall, Inc.

Kareem, I. (2013). Effects of phosphorus fertilizer treatments on vegetative growth, tuberous yield and phosphorus uptake of sweet potato (Ipomoea batatas). African Journal of Agricultural Research, 8(22), 2681-2684. https://doi. org/10.5897/AJAR10.224

Khan, B.A., Warner, P. and Wang, H. (2014). Antibacterial properties of hemp and other natural fibre plants: A review. BioResources, 9(2), 3642-3659. (https://ojs.cnr.ncsu.edu/ index.php/BioRes/article/download/BioRes_09_2_Khan_ Antibacterial_Hemp_Fibre_Review/2773)

Leizer, C., Ribnicky, D., Poulev, A., Dushenkov, S., and Raskin, I. (2000). The composition of hemp seed oil and its potential as an important source of nutrition. Journal of Nutraceuticals, Functional \& Medical Foods, 2(4), 35-53. https:// doi.org/10.1300/J133v02n04_04

Madras, B. K. (2015). Update of cannabis and its medical use. In Proceedings of the 37th Meeting of the Expert Committee on Drug Dependence. November 16-20, Geneva, Switzerland: The World Health Organization. Retrieved from https:// www.who.int/medicines/access/controlled-substances/6_2_cannabis_update.pdf.

Maobe, S. N., Akundabweni, L. S. M., Mburu, M. W. K., Ndufa, J. K., Mureithi, J. G., Gachene, C. K. K., Makini, F. W., and Okello, J. J. (2010). Effect of mucuna green manure and inorganic fertilizer urea nitrogen sources and application rates on harvest index of maize (Zea mays L.). World Journal of Agricultural Sciences, 6(5), 532-539. (https://www. idosi.org/wjas/wjas6 (5)/10.pdf)

Marjanović-Jeromela, A., Marinković, R., Mijić, A., Jankulovska, M., and Zdunić, Z. (2007). Inter-relationship between oil yield and other quantitative traits in rapeseed (Brassica napus L.). Journal of Central European Agriculture, 8(2), 165-170.

Milewicz, M., and Sawicki, J. (2012). Mechanisms of sex determination in plants. Časopis Slezského Zemského Muzea (A), 61(2), 123-129. https://doi.org/10.2478/v10210-0120013-3

Mohammadi, M., Tobeh, A., Vahidpour, H. R., and Fakhari, R. (2013). Effects of biological fertilizers on essential oil components and quantitative and qualitative yield of lemon verbena (Lippia citriodora). International Journal of Agriculture and Crop Sciences, 5, 1374-1380.

Minotti, P. L., Williams, D. C., and Jackon, W. A. (1969). Nitrate uptake by wheat as influenced by ammonium and other cations. Crop Science, 9, 9-14. https://doi.org/10.2135/crops ci1969.0011183X000900010003x

Mullins, G. (2009). Phosphorus, agriculture and the environment. Virginia Cooperative Extension; Virginia State University. (Crop and Soil Environmental Sciences). Retrieved from http://pubs.ext.vt.edu/424/424-029/424-029.html.

Murata, Y. (1969). Physiological responses to nitrogen in plants. In D. E. Jerry, Haskins, F. A. Sullivan, C. Y. Van Bavel, C. H. M., and Dinauer, R. C. (Eds.), Proceedings of a Symposium on Physiological Aspects of Crop Yield (pp. 235-259). Lin- 
coln, Nebraska: University of Nebraska. American Society of Agronomy \& Crop Science Society of America. https:// doi.org/10.2135/1969.physiologicalaspects.c27

Papastylianou, P., Kakabouki, I., and Travlos, I. (2018). Effect of nitrogen fertilization on growth and yield of industrial hemp (Cannabis sativa L.). Notulae Botanicae Horti Agrobotanici Cluj-Napoca, 46, 197-201. https://doi.org/10.15835/ nbha46110862

Peiretti, P. G. (2009). Influence of the growth stage of hemp (Cannabis sativa L.) on fatty acid content, chemical composition and gross energy. Agricultural Journal, 4, 27-31. (http://medwelljournals.com/abstract/?doi=aj.2009.27.31)

Poisa, L., and Adamovics, A. (2010). Hemp (Cannabis sativa L.) as an environmentally friendly energy plant. Environmental and Climate Technologies 5, 80-85. https://doi.org/10.2478/ v10145-010-0038-z

Rajesware Rao, B. R., Singh, K., Kaul, P. N., and Bhattacharya, A. K. (1989). The effect of plant spacing and application of $\mathrm{N}$ and $\mathrm{P}$ fertilizers on the productivity and nutrient uptake of davana (Artemisia pallens Wall). International Journal of Tropical Agriculture 7, 229-236.

Rathke, G. W., Christen, O., and Diepenbrock, W. (2005). Effects of nitrogen source and rate on productivity and quality of winter oilseed rape (Brassica napus L.) grown in different crop rotations. Field Crops Research, 94,103-113. https://doi.org/10.1016/j.fcr.2004.11.010

Reed, A. J., Singletary, G. W., Schussler, J. R., Willianmson, D. R., and Christy A. L. 1988. Shading effects on dry matter and nitrogen partitioning, kernel number, and yield of maize. Crop Science, 28, 819-825. https://doi.org/10.2135/ cropsci1988.0011183X002800050020x

Riahi, L., Shokrpour, M., Salami, S. A., and Khandan, A. (2016). Study of some quantitative traits associations and their application in characterization of Iranian accessions of Cannabis (Cannabis sativa L.). Iranian Journal of Filed Crop Science, 46(4), 629-639. https://doi.org/10.22059/ ijfcs.2015.56812
Rurangwa, E., Vanlauwe, B., and Giller, K. E. (2018). Benefits of inoculation, $\mathrm{P}$ fertilizer and manure on yields of common bean and soybean also increase yield of subsequent maize. Agriculture, Ecosystems and Environment, 261, 219-229. https://doi.org/10.1016/j.agee.2017.08.015

Shams, A., Abadian, H., Akbari, G., Koliai, A., and Zeinali, H., 2012. Effect of organic and chemical fertilizers on amount of essence, biological yield and harvest index of Matricaria chamomile. Annals of Biological Research, 3(8), 3856-3860.

Shams, A., Asadi Kapourchal, S., and Shakouri, M. J. (2013). Assessing the effect of nitrogen and phosphorus fertilizers on yield of Thymus daenensis under dry farming condition. Middle-East Journal of Scientific Research, 13(6), 793-797.

Thomas, B. F., and Pollard, G. T., (2016). Preparation and distribution of cannabis and cannabis-derived dosage formulations for investigational and therapeutic use in the United States. Frontiers in Pharmacology, 7, 285. https://doi. org/10.3389/fphar.2016.00285.

Truta, E., Olteanu, Z., Surdu, S., Zamfirache, M. M., and Oprica, L. (2007). Some aspects of sex determinism in hemp. Secţiunea Genetică şi Biologie Moleculară (Journal of Experimental and Molecular Biology), 8(2), 31-39.

Walkley, A., and Black, I. A. (1934). An examination of the Degtjareff method for determining soil organic matter and a proposed modification of the chromic acid titration method. Soil Science, 37(1), 29-38.

Yadav, R. D., Keshwa, G. L. and Yadva. S. S. (2002). Effect of integrated use of FYM, urea and sulphur on growth and yield of isabgol (Plantago ovata). Journal of Medicinal and Aromatic Plant Sciences, 25, 668-671.

Zahedifard, M., Sharafzadeh, Sh., Zolfibavariani, M., and Zare, M. (2014). Influence of nitrogen and vermicompost on grain and oil yield of rapeseed CV. RGS003. Bulletin of Environment, Pharmacology and Life Sciences, 3(7), 54-57. http://www.bepls.com/june_2014/10.pdf 